Article

\title{
Structural Variation of Bamboo Lignin before and after Ethanol Organosolv Pretreatment
}

\author{
Yuan-Yuan Bai ${ }^{1, \dagger}$, Ling-Ping Xiao ${ }^{1, \dagger}$, Zheng-Jun Shi ${ }^{1}$ and Run-Cang Sun ${ }^{1,2, *}$ \\ 1 Beijing Key Laboratory of Lignocellulosic Chemistry, Beijing Forestry University, Beijing 100083, \\ China; Emails: yuanhai_9@126.com (Y.-Y.B.); lingpingxiao@gmail.com (L.-P.X.); \\ km-szj@163.com (Z.-J.S.)
}

2 State Key Laboratory of Pulp and Paper Engineering, South China University of Technology, Guangzhou 510640, China

$\dagger$ These authors contributed equally to this work.

* Authors to whom correspondence should be addressed; E-Mail: rcsun3@ bjfu.edu.cn; Tel./Fax: +86-10-62336903.

Received: 18 September 2013; in revised form: 5 October 2013 / Accepted: 10 October 2013 / Published: 28 October 2013

\begin{abstract}
In order to make better use of lignocellulosic biomass for the production of renewable fuels and chemicals, it is necessary to disrupt its recalcitrant structure through pretreatment. Specifically, organosolv pretreatment is a feasible method. The main advantage of this method compared to other lignocellulosic pretreatment technologies is the extraction of high-quality lignin for the production of value-added products. In this study, bamboo was treated in a batch reactor with $70 \%$ ethanol at $180{ }^{\circ} \mathrm{C}$ for $2 \mathrm{~h}$. Lignin fractions were isolated from the hydrolysate by centrifugation and then precipitated as ethanol organosolv lignin. Two types of milled wood lignins (MWLs) were isolated from the raw bamboo and the organosolv pretreated residue separately. After the pretreatment, a decrease of lignin (preferentially guaiacyl unit), hemicelluloses and less ordered cellulose was detected in the bamboo material. It was confirmed that the bamboo MWL is of HGS type (p-hydroxyphenyl $(\mathrm{H})$, vanillin $(\mathrm{G})$, syringaldehyde $(\mathrm{S})$ ) associated with a considerable amount of $p$-coumarate and ferulic esters of lignin. The ethanol organosolv treatment was shown to remove significant amounts of lignin and hemicelluloses without strongly affecting lignin primary structure and its lignin functional groups.
\end{abstract}


Keywords: organosolv pretreatment; MWL; lignin; Py-GC/MS; HSQC NMR

\section{Introduction}

The energy crisis and climate change concerns caused by overuse of fossil fuels has led to a worldwide interest in sustainable biofuels [1]. Plant biomass, which is renewable and available in high amounts and relatively low cost, is an ideal source of sustainable energy and biobased products [2]. Most plant biomass is lignocellulosic and mainly consists of three biopolymers: cellulose, hemicelluloses, and lignin, which together form a complex and rigid structure [3].

Lignin is a complex aromatic heteropolymer that forms a matrix with hemicelluloses and together they account for $18 \%-40 \%$ of the total dry weight of the plant [4]. The heterogeneous and highly cross-linked macromolecule of lignin is built up of different inter-unit linkages, such as $\beta-O-4, \beta-\beta$, $\beta-5, \beta-1,5-5,4-O-5$, etc. [5]. Moreover, lignin is linked by ether bonds between phenyl-propane units, which are not readily hydrolysable [6].

Among biomass feedstocks, Bamboo Dendrocalamus brandisii, belonging to Bambusoideae of Gramineae, has strong and abundant woody stems and is mainly distributed in southeast Asia including the southwest region of China [7]. Because of its easy propagation, fast growth, and high productivity, D. brandisii is considered one of the most potential non-wood forest feedstocks to replace wood resources. Various studies have been concerned with the lignin of bamboo material. However, the isolation, purification, and high-value application of lignin is still a challenge so far. Deriving lignin from the bamboo using organosolv fractionation processes might be a good choice to use the material as a fiber resource, if lignin and its derivatives can be obtained with added value when compared with that of similar synthetic compounds derived from oil.

Different kinds of physical and/or chemical pretreatments have been proposed for the conversion of wood and agricultural wastes [8]. Among these methods, the ethanol organosolv process is promising, since it allows clean fractionation of the biomass. Ethanol organosolv pretreatment allows an efficient fractionation of the raw material into a cellulose rich residue, a water soluble fraction mainly containing hemicellulosic sugars and large quantity of organosolv lignin fraction. Moreover, this process converts the recalcitrant lignocellulosic matrix to a reactive cellulosic substrate that can be readily digested by cellulase, resulting in a high conversion of cellulose to glucose [9]. Organosolv lignins are high-purity, low molecular weight and sulfur-free products. In addition, they are soluble in many organic solvents, possess low glass transition temperatures, and are easier to thermally process than Kraft lignins [10]. The knowledge of the structural changes imparted by pretreatments to carbohydrate and lignin structures can provide valuable information to understand the pretreatment mechanism and, thus, contribute to the improvement of current approaches or the development of new pretreatment methods [11]. Ethanol organosolv process is normally operated at a high temperature $\left(>150{ }^{\circ} \mathrm{C}\right)$ with or without the addition of catalysts.

Recently, the conversion of ethanol organosolv lignin (EOL) to a potential fuel precursor for green gasoline/diesel by catalytic hydrogenolysis has been demonstrated. Generally, milled wood lignin (MWL) is considered to be representative of the original lignin but it usually gives low yields and 
contains a significant amount of carbohydrate contamination [12]. Cellulolytic enzyme lignin (CEL) was found to be structurally similar, but it has a higher yield, so it is more representative of the total lignin in wood than MWL. The carbohydrate amount of CEL is lowered by cellulolytic enzyme treatment before solvent extraction [13]. However, all these methods usually require intensive ball milling of the biomass for a period of hours to weeks [13].

The aim of the present work was to elucidate the changes produced in the structure and composition of bamboo lignin before and after organosolv pretreatment. For this purpose, lignin from bamboo in native form, in fractionated form after organosolv pretreatment, and enzymatic pretreatment were thoroughly investigated. These lignin fractions have been extensively analyzed by using several spectroscopic and chromatographic non-destructive techniques, including ${ }^{13} \mathrm{C}$ nuclear magnetic resonance spectroscopy (NMR), heteronuclear single-quantum coherence (HSQC-NMR) spectroscopy, Fourier transform infrared (FT-IR), and gel permeation chromatography (GPC). Moreover, the untreated and pretreated bamboo materials were characterized by solid-state cross-polarization/magic angle spinning (CP/MAS) ${ }^{13} \mathrm{C}$ NMR and pyrolysis-gas chromatography/mass spectrometry (Py-GC/MS).

\section{Results and Discussion}

\subsection{Sugar Analysis}

The results of component analysis of the original and pretreated bamboo, and the carbohydrate analysis of the isolated lignin samples are summarized in Table 1. The composition of untreated bamboo was determined to be $47.2 \%$ cellulose, $23.9 \%$ hemicelluloses, $23.8 \%$ Klason lignin, $1.5 \%$ acid-soluble lignin, and $1.4 \%$ ash on a dry weight. This result agrees well with recent analysis results reported by Shi et al. [14]. Compared with the raw material, the glucan of ethanol organosolv pretreated bamboo increased notably (52.3\%) but the Klason lignin decreased (17.3\%). The results of chemical analysis of the four isolated lignins indicated that glucan and xylan were the predominant carbohydrates and mannan was found only in very small amounts. Compared with $\mathrm{MWL}_{\mathrm{u}}$, the polysaccharides in EOL showed lower amounts of glucan, and relatively higher amounts of arabinan, xylan and galactan, indicating the removal of a large amount of the hemicellulosic content from the solid phrase during the treatment. This result was in accordance with the amount of sugar contents of $M_{\mathrm{W}}$. For CEL, the removal of carbohydrates using cellulase increased the yields of lignin in the following aqueous dioxane extraction [13,15], which was ascribed to the inclusion of lignin released from its physical and/or chemical association with carbohydrate by the enzyme treatment. Therefore, the CEL includes not only the lignin normally isolated as MWL, but also lignin, which was associated with carbohydrates, giving rise to the relatively higher content of carbohydrates [13]. REL contained two main sugars, which were glucan $(17.3 \%)$ and xylan $(4.5 \%)$, and this could be explained by the incorporation of the cellulose and hemicelluloses during the enzymatic treatment [16]. 
Table 1. Results of component analysis of the original and pretreated bamboo, and the carbohydrate analysis of the isolated lignin samples (\%).

\begin{tabular}{|c|c|c|c|c|c|c|}
\hline \multicolumn{2}{|c|}{ Chemical composition } & \multicolumn{2}{|c|}{ Untreated bamboo } & \multicolumn{3}{|c|}{ Pretreated bamboo } \\
\hline \multicolumn{2}{|c|}{ Cellulose (as glucan) } & \multicolumn{2}{|c|}{$47.24 \pm 1.15$} & \multicolumn{3}{|c|}{$52.34 \pm 0.32$} \\
\hline \multicolumn{2}{|c|}{ Hemicellulose sugars } & \multicolumn{2}{|c|}{$23.85 \pm 1.79$} & \multicolumn{3}{|c|}{$23.41 \pm 0.03$} \\
\hline \multicolumn{2}{|c|}{ Xylan } & \multicolumn{2}{|c|}{$22.12 \pm 1.53$} & \multicolumn{3}{|c|}{$22.53 \pm 0.03$} \\
\hline \multicolumn{2}{|c|}{ Arabinan } & \multicolumn{2}{|c|}{$1.24 \pm 0.23$} & \multicolumn{3}{|c|}{$0.68 \pm 0.00$} \\
\hline \multicolumn{2}{|c|}{ Galactan } & \multicolumn{2}{|c|}{$0.47 \pm 0.05$} & \multicolumn{3}{|c|}{$0.20 \pm 0.00$} \\
\hline \multicolumn{2}{|c|}{ Mannan } & \multicolumn{2}{|c|}{$0.07 \pm 0.00$} & \multicolumn{3}{|c|}{ ND } \\
\hline \multicolumn{2}{|c|}{ Galacturonic acid } & \multicolumn{2}{|c|}{$0.03 \pm 0.01$} & \multicolumn{3}{|c|}{ ND } \\
\hline \multicolumn{2}{|c|}{ Klason lignin } & \multicolumn{2}{|c|}{$23.84 \pm 1.09$} & \multicolumn{3}{|c|}{$17.27 \pm 0.11$} \\
\hline \multicolumn{2}{|c|}{ Acid-soluble lignin } & \multicolumn{2}{|c|}{$1.51 \pm 0.06$} & \multicolumn{3}{|c|}{$1.06 \pm 0.02$} \\
\hline \multicolumn{2}{|c|}{ Ash } & \multicolumn{2}{|c|}{$1.37 \pm 0.03$} & \multicolumn{3}{|c|}{$1.16 \pm 0.06$} \\
\hline Samples & Carb $^{\mathrm{a}}$ & $\operatorname{Ara}^{a}$ & $\mathrm{Gal}^{\mathrm{a}}$ & $\mathrm{Glc}^{\mathrm{a}}$ & Xly $^{a}$ & $\operatorname{Man}^{a}$ \\
\hline $\mathrm{MWL}_{\mathrm{u}}$ & $10.51 \pm 0.25$ & $0.22 \pm 0.05$ & $0.10 \pm 0.01$ & $6.68 \pm 0.05$ & $3.49 \pm 0.07$ & Trace \\
\hline $\mathrm{MWL}_{\mathrm{p}}$ & $8.11 \pm 0.87$ & $0.04 \pm 0.00$ & $0.02 \pm 0.00$ & $6.63 \pm 0.71$ & $1.43 \pm 0.15$ & Trace \\
\hline EOL & $5.26 \pm 0.42$ & $0.58 \pm 0.05$ & $0.32 \pm 0.02$ & $1.01 \pm 0.11$ & $3.35 \pm 0.22$ & Trace \\
\hline CEL & $12.24 \pm 1.24$ & $0.83 \pm 0.01$ & $0.49 \pm 0.02$ & $5.17 \pm 0.12$ & $4.79 \pm 0.92$ & $0.95 \pm 0.22$ \\
\hline REL & $24.96 \pm 1.38$ & $0.46 \pm 0.03$ & $0.92 \pm 0.05$ & $17.32 \pm 0.91$ & $4.47 \pm 0.30$ & $1.47 \pm 0.07$ \\
\hline
\end{tabular}

${ }^{\mathrm{a}}$ Carb, carbohydrate; Ara, arabinan; Gal, galactan; Glc, glucan; Man, mannan; Xyl, xylan.

\subsection{Pyrolysis-Gas Chromatography/Mass Spectrometry}

Py-GC/MS is a powerful tool for the in situ characterization of plant constituents. The material is pyrolyzed to produce a mixture of relatively simple phenols, which come from the cleavage of ether and carbon-carbon linkages. These phenols retain their substitution patterns from the lignin polymer, and it is thus possible to identify compounds from the H, G, and S lignin units [17].

The pyrograms of the untreated and pretreated bamboo and the identified compounds are shown in Figures 1 and 2. The identification and relative molar abundances of the released lignin breakdown products are shown in Table 2. Relative peak areas were calculated for pyrolysis products from phenylpropanoid compounds (including guaiacyl $(\mathbf{G})$ and syringyl-type (S) phenols), and the total areas of the peaks were normalized to $100 \%$ [18]. The pyrograms (Figure 1) show a series of products characteristic of pyrolysis of phenylpropanoid compounds in both untreated and pretreated bamboo. The main pyrolyzed products are $\mathrm{G}$ lignin derivatives (peaks 10, 12, 15, 27, 40, 41) and $\mathrm{S}$ lignin derivatives (peaks 18, 22, 32, 38). 
Figure 1. Pyrogram of (a) untreated and (b) ethanol organosolv pretreated bamboo. The structures of the labeled compounds are shown in Figure 2.
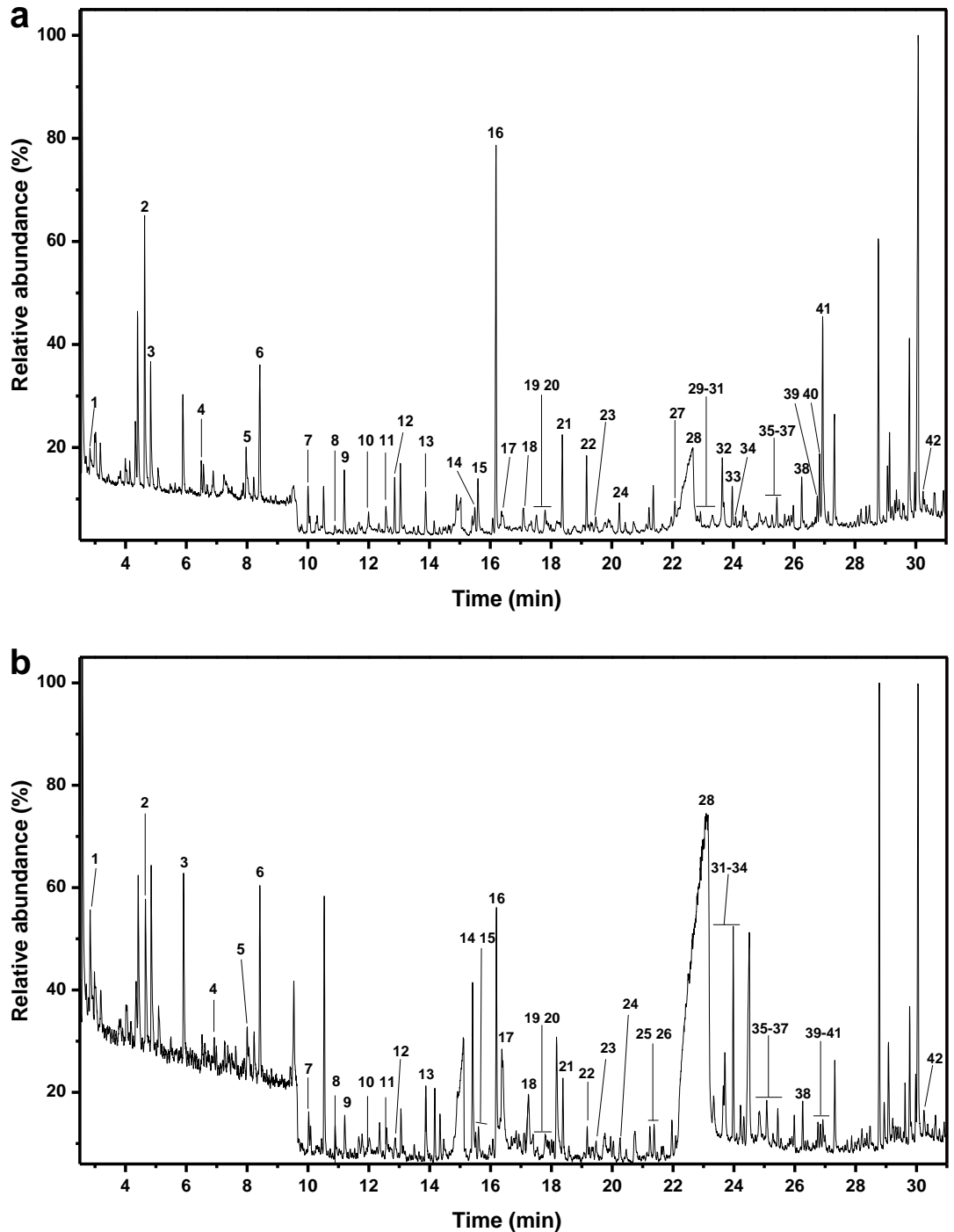

Figure 2. Compound structures. Assignments of all the structural compounds are labeled in Figure 1.

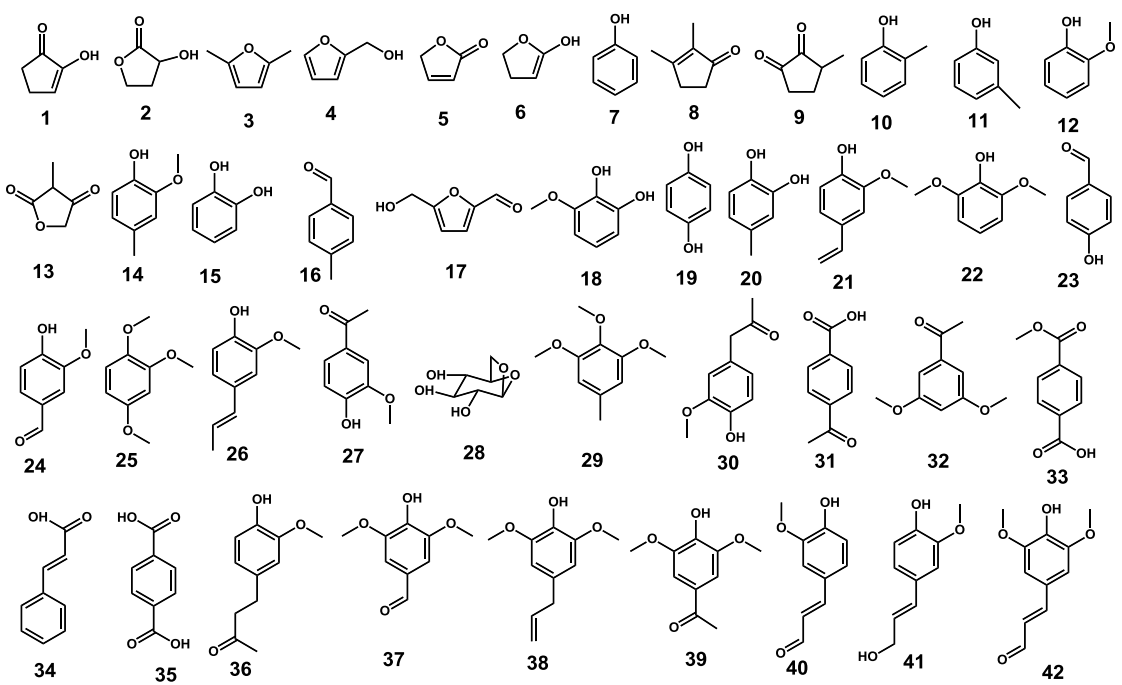


Table 2. Composition, retention time, formula, molecular weight $\left(\mathrm{M}_{w}\right)$ and relative molar abundance $(\%)$ of the compounds released after Py-GC/MS of bamboo.

\begin{tabular}{|c|c|c|c|c|c|c|}
\hline Label & R.T. (min) & Compound name & Formula & $\mathbf{M}_{w}$ & Untreated & Pretreated \\
\hline \multicolumn{7}{|c|}{ Carbohydrate derived compounds } \\
\hline 1 & 2.82 & 2-Cyclopenten-1-one, 2-hydroxy- & $\mathrm{C}_{5} \mathrm{H}_{6} \mathrm{O}_{2}$ & 98 & 0.9 & 1.6 \\
\hline 2 & 4.63 & 2-Hydroxy-gamma-butyrolactone & $\mathrm{C}_{4} \mathrm{H}_{6} \mathrm{O}_{3}$ & 102 & 6.5 & 2.2 \\
\hline 3 & 5.88 & Furan, 2,5-dimethyl- & $\mathrm{C}_{6} \mathrm{H}_{8} \mathrm{O}$ & 96 & 3.3 & 2.2 \\
\hline 4 & 6.49 & 2-Furanmethanol & $\mathrm{C}_{5} \mathrm{H}_{6} \mathrm{O}_{2}$ & 98 & 0.8 & 0.5 \\
\hline 5 & 7.97 & $2(5 H)$-furanone & $\mathrm{C}_{4} \mathrm{H}_{4} \mathrm{O}_{2}$ & 84 & 2.3 & 0.6 \\
\hline 6 & 8.42 & 2-Cyclopenten-1-one, 2-hydroxy- & $\mathrm{C}_{5} \mathrm{H}_{6} \mathrm{O}_{2}$ & 98 & 4.5 & 2.3 \\
\hline 8 & 10.89 & 2-Cyclopenten-1-one, 2-hydroxy-3-methyl- & $\mathrm{C}_{6} \mathrm{H}_{8} \mathrm{O}_{2}$ & 112 & 0.3 & 0.6 \\
\hline 9 & 11.20 & 1,2-Cyclopentanedione, 3-methyl- & $\mathrm{C}_{6} \mathrm{H}_{8} \mathrm{O}_{2}$ & 112 & 1.8 & 0.6 \\
\hline 13 & 13.87 & 2,4(3H,5H)-furandione, 3-methyl- & $\mathrm{C}_{5} \mathrm{H}_{6} \mathrm{O}_{3}$ & 114 & 1.4 & 1.1 \\
\hline 17 & 16.38 & 2-Furancarboxaldehyde, 5-(hydroxymethyl)- & $\mathrm{C}_{6} \mathrm{H}_{6} \mathrm{O}_{3}$ & 126 & 1.1 & 2.3 \\
\hline \multirow[t]{2}{*}{28} & 22.67 & $\beta$-D-Glucopyranose, 1,6-anhydro- & $\mathrm{C}_{6} \mathrm{H}_{10} \mathrm{O}_{5}$ & 162 & 21.0 & 65.8 \\
\hline & Sum & & & & 43.9 & 79.9 \\
\hline \multicolumn{7}{|c|}{ Lignin guaiacyl-type } \\
\hline 10 & 12.00 & Phenol, 2-methyl- & $\mathrm{C}_{7} \mathrm{H}_{8} \mathrm{O}$ & 108 & 1.2 & 0.4 \\
\hline 12 & 12.85 & Phenol, 2-methoxy- & $\mathrm{C}_{7} \mathrm{H}_{8} \mathrm{O}_{2}$ & 124 & 1.5 & 0.4 \\
\hline 14 & 15.49 & Phenol, 2-methoxy-4-methyl- & $\mathrm{C}_{8} \mathrm{H}_{10} \mathrm{O}_{2}$ & 138 & 0.9 & 0.3 \\
\hline 15 & 15.59 & 1,2-Benzenediol & $\mathrm{C}_{6} \mathrm{H}_{6} \mathrm{O}_{2}$ & 110 & 1.8 & 0.5 \\
\hline 20 & 17.80 & 1,2-Benzenediol, 4-methyl- & $\mathrm{C}_{7} \mathrm{H}_{8} \mathrm{O}_{2}$ & 124 & 0.9 & 0.5 \\
\hline 21 & 18.37 & 2-Methoxy-4-vinylphenol & $\mathrm{C}_{9} \mathrm{H}_{10} \mathrm{O}_{2}$ & 150 & 2.8 & 0.9 \\
\hline 24 & 20.25 & Vanillin & $\mathrm{C}_{8} \mathrm{H}_{8} \mathrm{O}_{3}$ & 152 & 1.1 & 0.4 \\
\hline 25 & 21.23 & 1,2,4-Trimethoxybenzene & $\mathrm{C}_{9} \mathrm{H}_{12} \mathrm{O}_{3}$ & 168 & 0.7 & 0.4 \\
\hline 26 & 21.37 & Phenol, 2-methoxy-4-(1-propenyl)- & $\mathrm{C}_{10} \mathrm{H}_{12} \mathrm{O}_{2}$ & 164 & 1.2 & 0.4 \\
\hline 27 & 22.07 & Ethanone, 1-(4-hydroxy-3-methoxyphenyl)- & $\mathrm{C}_{9} \mathrm{H}_{10} \mathrm{O}_{3}$ & 166 & 1.6 & 0.3 \\
\hline 30 & 22.92 & 2-Propanone, 1-(4-hydroxy-3-methoxyphenyl)- & $\mathrm{C}_{10} \mathrm{H}_{12} \mathrm{O}_{3}$ & 180 & 0.4 & Trace \\
\hline 36 & 25.27 & 2-Butanone, 4-(4-hydroxy-3-methoxyphenyl)- & $\mathrm{C}_{11} \mathrm{H}_{14} \mathrm{O}_{3}$ & 194 & 0.5 & 0.2 \\
\hline 40 & 26.84 & 2-Propenal, 3-(4-hydroxy-3-methoxyphenyl)- & $\mathrm{C}_{10} \mathrm{H}_{10} \mathrm{O}_{3}$ & 178 & 1.6 & 0.2 \\
\hline \multirow[t]{2}{*}{41} & 26.94 & 4-((1E)-3-Hydroxy-1-propenyl)-2-methoxyphenol & $\mathrm{C}_{10} \mathrm{H}_{12} \mathrm{O}_{3}$ & 180 & 6.4 & 0.4 \\
\hline & Sum & & & & 22.7 & 5.3 \\
\hline \multicolumn{7}{|c|}{ Lignin syringyl-type } \\
\hline 18 & 17.08 & 1,2-Benzenediol, 3-methoxy- & $\mathrm{C}_{7} \mathrm{H}_{8} \mathrm{O}_{3}$ & 140 & 1.1 & 0.3 \\
\hline 22 & 19.17 & Phenol, 2,6-dimethoxy- & $\mathrm{C}_{8} \mathrm{H}_{10} \mathrm{O}_{3}$ & 154 & 1.9 & 0.4 \\
\hline 29 & 22.82 & Benzene, 1,2,3-trimethoxy-5-methyl- & $\mathrm{C}_{10} \mathrm{H}_{14} \mathrm{O}_{3}$ & 182 & 0.5 & Trace \\
\hline 32 & 23.63 & 3',5'-Dimethoxyacetophenone & $\mathrm{C}_{10} \mathrm{H}_{12} \mathrm{O}_{3}$ & 180 & 2.4 & 0.7 \\
\hline 37 & 25.43 & Benzaldehyde, 4-hydroxy-3,5-dimethoxy- & $\mathrm{C}_{9} \mathrm{H}_{10} \mathrm{O}_{4}$ & 182 & 0.9 & 0.4 \\
\hline 38 & 26.25 & Phenol, 2,6-dimethoxy-4-(2-propenyl)- & $\mathrm{C}_{11} \mathrm{H}_{14} \mathrm{O}_{3}$ & 194 & 1.6 & 0.5 \\
\hline 39 & 26.76 & Ethanone, 1-(4-hydroxy-3,5-dimethoxyphenyl)- & $\mathrm{C}_{10} \mathrm{H}_{12} \mathrm{O}_{4}$ & 196 & 0.7 & 0.3 \\
\hline \multirow[t]{2}{*}{43} & 30.25 & 3,5-Dimethoxy-4-hydroxycinnamaldehyde & $\mathrm{C}_{11} \mathrm{H}_{12} \mathrm{O}_{4}$ & 208 & 0.6 & 0.4 \\
\hline & Sum & & & & 9.7 & 3.1 \\
\hline
\end{tabular}


Table 2. Cont.

\begin{tabular}{ccccccc}
\hline Label & R.T. $(\mathbf{m i n})$ & Compound name & Formula & $\mathbf{M}_{w}$ & Untreated & Pretreated \\
\hline \multicolumn{7}{c}{} \\
7 & 10.01 & Other lignin derived products & & & \\
11 & 12.57 & Phenol & $\mathrm{C}_{6} \mathrm{H}_{6} \mathrm{O}$ & 94 & 1.4 & 0.5 \\
16 & 16.19 & Phenol, 3-methyl- & $\mathrm{C}_{7} \mathrm{H}_{8} \mathrm{O}_{2}$ & 108 & 1.0 & 0.5 \\
19 & 17.52 & 4-Methyl-benzaldehyde & $\mathrm{C}_{8} \mathrm{H}_{8} \mathrm{O}$ & 120 & 10.0 & 2.6 \\
23 & 19.47 & Hydroquinone & $\mathrm{C}_{6} \mathrm{H}_{6} \mathrm{O}_{2}$ & 110 & 0.9 & 0.2 \\
31 & 23.31 & Benzaldehyde, 4-hydroxy- & $\mathrm{C}_{7} \mathrm{H}_{6} \mathrm{O}_{2}$ & 122 & 0.7 & 0.3 \\
33 & 23.69 & 4-Acetylbenzoic acid & $\mathrm{C}_{9} \mathrm{H}_{8} \mathrm{O}_{3}$ & 164 & 0.9 & 1.2 \\
34 & 24.07 & 1,4-Benzenedicarboxylic acid, methyl ester & $\mathrm{C}_{9} \mathrm{H}_{8} \mathrm{O}_{4}$ & 180 & 0.9 & 1.3 \\
35 & 25.07 & trans-Cinnamic acid & $\mathrm{C}_{9} \mathrm{H}_{8} \mathrm{O}_{2}$ & 148 & 0.3 & 0.1 \\
& Sum & 1,4-Benzenedicarboxylic acid & $\mathrm{C}_{8} \mathrm{H}_{6} \mathrm{O}_{4}$ & 166 & 0.9 & 0.6 \\
& S/G & & & & 16.8 & 7.4 \\
& & & & 0.4 & 0.6 \\
\hline
\end{tabular}

In the case of the untreated bamboo sample, the estimated $S / G$ ratio of the aromatic fraction was 0.4 ; in contrast, the $\mathrm{S} / \mathrm{G}$ ratio calculated for the pretreated material sample was 0.6 . The result revealed a decreased G-derived lignin content in the pretreated bamboo sample, indicating a preferential lignin degradation site at the G-units.

\subsection{FT-IR Spectra}

FT-IR spectroscopy was further used to analyze the structural changes of the lignin fractions. The spectra and assignments are shown in Figure 3 and Table S1 in the Supplementary material. Despite some differences, $\mathrm{MWL}_{\mathrm{u}}, \mathrm{MWL}_{\mathrm{p}}, \mathrm{EOL}$, and CEL spectra profiles are rather similar as a whole, indicating a comparable chemical structure of those extracted lignins. They all showed strong hydroxyl bond (O-H) stretching at $3401 \mathrm{~cm}^{-1}$ and $\mathrm{C}-\mathrm{H}$ stretching vibrations at 2939/2847 $\mathrm{cm}^{-1}$. The bands between 1790 and $1680 \mathrm{~cm}^{-1}$ are characteristic of carbonyls. The bands at $1705 \mathrm{~cm}^{-1}$ and $1655 \mathrm{~cm}^{-1}$, observed in $\mathrm{MWL}_{\mathrm{u}}$, are assigned to carbonyl stretching in unconjugated ketones and conjugated carbonyl groups, which can be mainly attributed to the coumaryl ester group, respectively. The intensity of these two bands decreased from the spectra of $M W L_{u}$ to $M W L_{p}$ to EOL and to CEL, and almost disappeared in that of REL. In addition, the intensity of the band at $1362 \mathrm{~cm}^{-1}$ showed the same tendency. It originates from the aliphatic $\mathrm{C}-\mathrm{H}$ stretch in methyl (not in methoxyl) and phenolic hydroxyl groups. The bands at 1593,1504 , and $1423 \mathrm{~cm}^{-1}$ arise from the aromatic skeletal vibrations. The absorption at $1458 \mathrm{~cm}^{-1}$ is attributed to the $\mathrm{C}-\mathrm{H}$ asymmetric deformations. The signal of the typical C-H band of acetyl methyl group observed at $1362 \mathrm{~cm}^{-1}$ in $\mathrm{MWL}_{\mathrm{u}}$ was stronger than that of other lignin fractions. The absorptions at the wavelengths of 1327 and $1122 \mathrm{~cm}^{-1}$ correspond to syringyl units and those at around 1261 and $1161 \mathrm{~cm}^{-1}$ belong to guaiacyl units. As compared with $\mathrm{MWL}_{\mathrm{u}}$, a decrease in intensity was observed at $1122 \mathrm{~cm}^{-1}$ of $\mathrm{MWL}_{\mathrm{p}}$, which is assigned to aromatic skeletal and $\mathrm{C}-\mathrm{O}$ stretch [19]. The band at $1030 \mathrm{~cm}^{-1}$ is attributed to aromatic $\mathrm{C}-\mathrm{H}$ in-plane deformation vibrations, and the absorption at $833 \mathrm{~cm}^{-1}$ is due to $\mathrm{C}-\mathrm{H}$ out-of-plane stretching [20]. The spectra of REL exhibited typical absorptions at $1152 \mathrm{~cm}^{-1}$ which was attributed to the association of xyloglucan. The absorption at $891 \mathrm{~cm}^{-1}$ is a typical absorption of the obstinate cellulose during the enzymatic treatment. This finding is consistent with the results obtained from the sugar analysis. 
Because the $\mathrm{C}=\mathrm{O}$ vibrations cause a band at around $1270 \mathrm{~cm}^{-1}$, the absorbance here is higher than in the case of standard GS spectra. Another important spectral feature of HGS lignin is the intense band at $833 \mathrm{~cm}^{-1}$ (the aromatic $\mathrm{C}-\mathrm{H}$ out of plain vibrations in $\mathrm{H}$ unit). Moreover, the presence of the band at $1161 \mathrm{~cm}^{-1}$ always permits a clear assignment to the HGS type [21].

Figure 3. FT-IR of the lignin fractions.

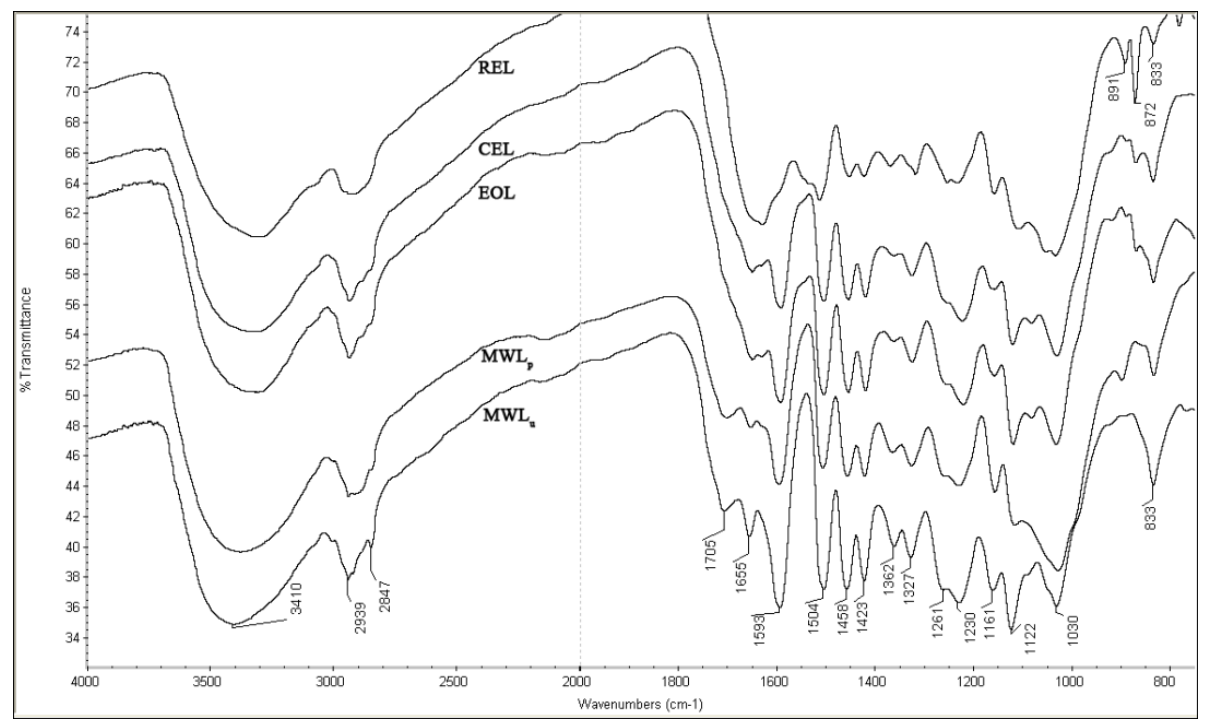

\subsection{Molecular Weight Distribution}

Lignin samples are only slightly soluble in tetrahydrofuran (THF), a common solvent used for gel permeation chromatography (GPC). Therefore, the ball-milled lignin fractions were acetylated using acetic anhydride/pyridine. The values of the weight-average $\left(M_{w}\right)$, number-average $\left(M_{n}\right)$ molecular weights and the dispersity $\left(\mathrm{M}_{\mathrm{w}} / \mathrm{M}_{\mathrm{n}}\right)$ of the lignin fractions are displayed in Table 3 [1]. Lignins are highly branched heterogeneous materials, and polystyrene equivalent "molecular weights" are only rough indications of molecular size based on hydrodynamic volume. The molecular weight of $\mathrm{MWL}_{\mathrm{u}}$ was smaller than that of $\mathrm{MWL}_{\mathrm{p}}$ in the acetylated form, and the EOL extracted after ethanol organosolv pretreatment exhibited a decrease in molecular weight but an increase of the dispersity index. This could be due to the higher solubility of low-molecular-weight lignins with branched and cross-linked structures in the ethanol/water solvent. However, the condensed lignin was much more difficult to be fractionated or get it dissolved in the pulping processes [11]. In addition, all lignin fractions possessed relatively narrow molecular weight distributions, as shown by $\mathrm{M}_{\mathrm{w}} / \mathrm{M}_{\mathrm{n}}<3$.

Table 3. Weight average $\left(\mathrm{M}_{w}\right)$ and number average $\left(\mathrm{M}_{n}\right)$ molecular weights and dispersity $\left(\mathrm{M}_{w} / \mathrm{M}_{n}\right)$ index of the acetylated fractionated lignin samples.

\begin{tabular}{ccccc}
\hline Heading & MWL $_{\mathbf{u}}$ & MWL $_{\mathbf{p}}$ & EOL & CEL \\
\hline $\mathbf{M}_{w}(\mathrm{~g} / \mathrm{mol})$ & 7692 & 10657 & 5873 & 15307 \\
$\mathrm{M}_{n}(\mathrm{~g} / \mathrm{mol})$ & 4406 & 5997 & 3072 & 9721 \\
$\mathrm{M}_{w} / \mathrm{M}_{n}$ & 1.75 & 1.78 & 1.91 & 1.57 \\
\hline
\end{tabular}




\subsection{HSQC NMR Spectra}

In order to get additional information on the lignin structure, bamboo lignin samples, which were obtained from different isolation procedures, were analyzed by 2D NMR. The lignin spectra are deposited in Figure 4, and the main lignin correlation assignments are presented in Table 4 by comparing with the literature data [2,22-26]; the main substructures are illustrated in Figure 5.

In the side chain region of lignin, the intense signals showed the presence of the major interunits linkages including $\beta-O-4$ ' aryl ether (structure $\mathbf{A}$ ), resinol (structure B), phenylcoumaran $(\mathbf{C}$ ), and spirodiene structures (structure $\mathbf{D}$ ) and so on. The $\mathrm{C}-\mathrm{H}$ correlations in structure $\mathbf{A}$ were observed for $\alpha$ - and $\gamma$-C positions at $\delta_{\mathrm{C}} / \delta_{\mathrm{H}} 72.4 / 4.85$ and $60.1 / 3.22 \mathrm{ppm}$, respectively. HSQC analysis demonstrated that $\mathrm{MWL}_{\mathrm{p}}$ and EOL had a lower signal intensity of $\beta-O-4$ ' linkage when compared with $\mathrm{MWL}_{\mathrm{u}}$. El Hage et al. [27] suggested that the scission of $\beta-O-4$ ' linkages was the major mechanism of lignin breakdown during organosolv pretreatment of lignin from Miscanthus $\times$ giganteus. The $\beta$-correlations from $\beta$-aryl ether units clearly separate into these respective $G$ and $S$ types, namely, $\mathbf{A}_{\boldsymbol{\beta}}(\mathbf{G})$ and $\mathbf{A}_{\boldsymbol{\beta}}(\mathbf{S})$ and confirmed at $\delta_{\mathrm{C}} / \delta_{\mathrm{H}} 83.6 / 4.30$ and $85.8 / 4.10$, respectively. The spectra showed the presence of intense signals at $\delta_{\mathrm{C}} / \delta_{\mathrm{H}} 62.8 / 4.28$ corresponding to the $\gamma-\mathrm{C} / \mathrm{H}$ of $\gamma$-acylated units (structure $\mathbf{A}_{\gamma}^{\prime}$ ). Therefore, the HSQC spectra implied that these lignins were extensively acylated at the $\gamma$-position of the lignin side chain. Structure $\mathbf{B}$ was evidenced by $\mathrm{C}-\mathrm{H}$ correlations at $\delta_{\mathrm{C}} / \delta_{\mathrm{H}} 84.7 / 4.65,53.5 / 3.05$, 71.0/4.17 and 70.9/3.80 ppm for $\mathrm{C}_{\alpha}-\mathrm{H}_{\alpha}, \mathrm{C}_{\beta}-\mathrm{H}_{\beta}$, and $\mathrm{C}_{\gamma}-\mathrm{H}_{\gamma}$, respectively. The presence of structure $\mathbf{C}$ was verified by its $\mathrm{C} / \mathrm{H}$ correlations for $\alpha-, \beta-, \gamma-\mathrm{C}$ positions at $\delta_{\mathrm{C}} / \delta_{\mathrm{H}} 87.1 / 5.45,53.2 / 3.43$, 62.4/3.71 ppm, respectively. Small signal corresponding to structure $\mathbf{D}$ could also be observed in the

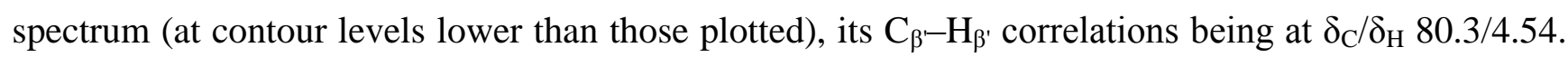
Minor amounts of cinnamyl alcohol-end groups $\left(\mathbf{I}_{\gamma}\right)$ could also be detected in the HSQC spectrum of the untreated MWL, as revealed by the $\mathrm{C}_{\alpha}-\mathrm{H}_{\alpha}$ correlations at $\delta_{\mathrm{C}} / \delta_{\mathrm{H}} 61.4 / 4.09$. In the lignin spectra (Figure $4 \mathrm{~b}-\mathrm{d}$ ), a dramatic decrease in side chain linkages was observed, and the corresponding cross-signals showed very low intensities and were even absent. All of these results indicated the extensive breakdown of $\beta-O-4$ ' linkages during the ethanol organosolv treatment.

Figure 4. Side-chain $\left(\delta_{\mathrm{C}} / \delta_{\mathrm{H}}\right.$ 50-90/2.5-6.1) region in the HSQC NMR spectra of (a) $\mathrm{MWL}_{\mathrm{u}}$; (b) $\mathrm{MWL}_{\mathrm{p}}$; (c) EOL and (d) CEL; Aromatic $\left(\delta_{\mathrm{C}} / \delta_{\mathrm{H}} 95-160 / 5.8-8.0\right)$ region in the HSQC NMR spectra of (e) MWL ; (f) MWL ; (g) EOL; and (h) CEL.

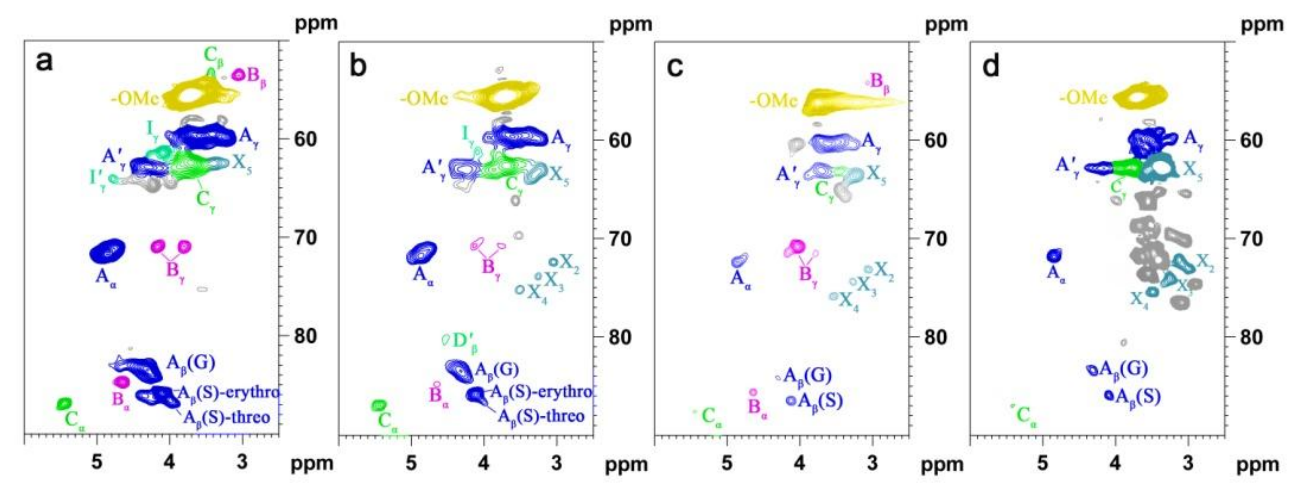


Figure 4. Cont.

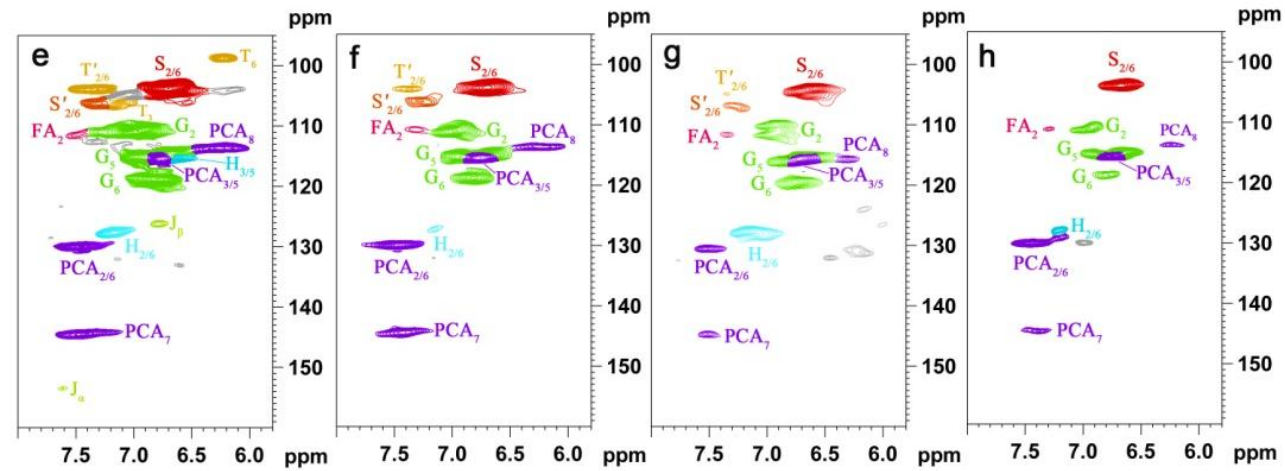

Figure 5. Main substructures present in the lignin fractions of bamboo (D. brandisii), as revealed as 2D HSQC NMR: (A) $\beta-O-4^{\prime}$ substructures; (A') $\beta-O-4$ ' substructures with acylated $\gamma-\mathrm{OH}$; (B) resinol substructures formed by $\beta-\beta^{\prime}$ coupling; (C) phenylcoumaran substructures formed by $\beta-5$ ' coupling; (D) spirodienone substructure formed by $\beta-1$ ' coupling; (I) cinnamyl alcohol end-groups; (J) cinnamyl aldehyde end-groups; (PCA) p-coumarate units; (FA) ferulate units; (H) p-hydroxyphenyl units; (G) guaiacyl units; (S) syringyl units; ( $\left.\mathbf{S}^{\prime}\right)$ oxidized syringyl units bearing a carbonyl at $\mathrm{C}_{\alpha} ;(\mathbf{T})$ a likely incorporation of tricin into the lignin polymer through a G-type $\beta-O-4$ ' linkage.
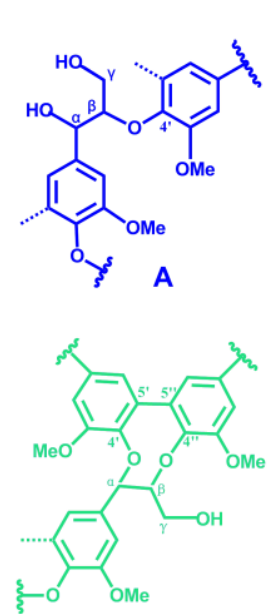

D

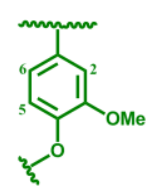

$\mathbf{G}$
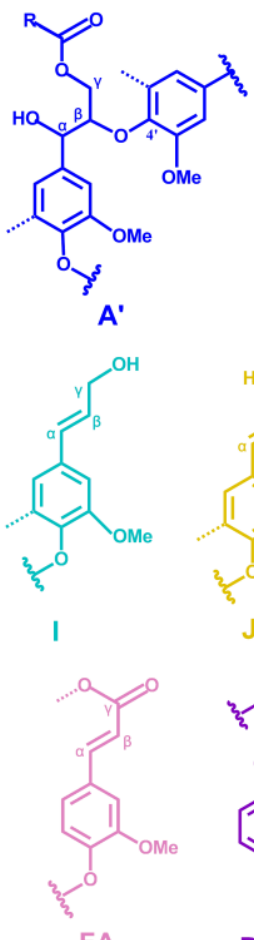

FA

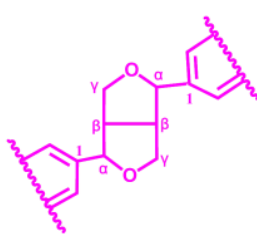

B

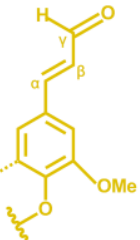

$J$

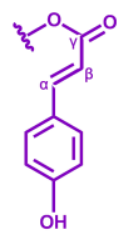

PCA

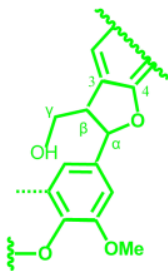

C
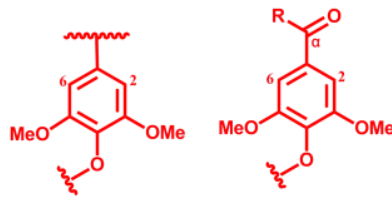

$S^{\prime}$

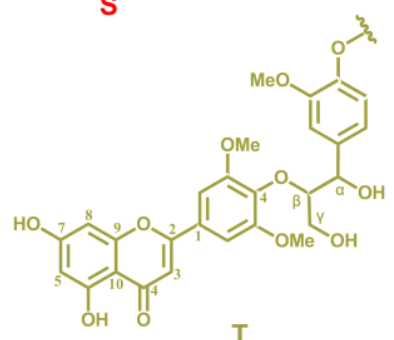

The aromatic ${ }^{13} \mathrm{C}-{ }^{1} \mathrm{H}$ region offers information on lignin constitutive units (such as $\mathbf{S}$ and $\mathbf{G}$ units), some of them bearing oxidized side chains. The cross-peaks for $\mathbf{S}_{\mathbf{2} / \mathbf{6}}$ and $\mathbf{G}_{\mathbf{2}}$ were observed at $\delta_{\mathrm{C}} / \delta_{\mathrm{H}}$ 104.3/6.70 and 111.1/6.97, respectively. Signals for $\mathrm{C}_{2,6}-\mathrm{H}_{2,6}$ of $\mathbf{H}$ units at $\delta_{\mathrm{C}} \delta_{\mathrm{H}}$ 128.0/7.17 were also detected in the HSQC spectra, although in lower amounts. This confirmed that the H-unit content in the lignins from these bamboo samples, similarly as in other grasses, was quite low ( 3\%, Table 5). 
Signals corresponding to $\mathrm{C}_{2,6}-\mathrm{H}_{2,6}$ correlations in $\mathrm{C}_{\alpha}$-oxidized S-lignin units $\left(\mathbf{S}^{\prime}\right)$ were observed at $\delta_{\mathrm{C}} / \delta_{\mathrm{H}} 106.3 / 7.30$. The $\mathrm{G}$ units displayed different correlations for $\mathrm{C}_{2}-\mathrm{H}_{2}, \mathrm{C}_{5}-\mathrm{H}_{5}$ and $\mathrm{C}_{6}-\mathrm{H}_{6}$ as $\mathbf{G}_{\mathbf{2}}, \mathbf{G}_{\mathbf{5}}$, and $\mathbf{G}_{6}$. Small signals correspond to $\mathrm{C}_{\alpha}-\mathrm{H}_{\alpha}$ correlations (at $\delta_{\mathrm{C}} / \delta_{\mathrm{H}} 153.5 / 7.61 \mathrm{ppm}$ ) and $\mathrm{C}_{\beta}-\mathrm{H}_{\beta}$ correlations (at $\delta_{\mathrm{C}} / \delta_{\mathrm{H}}$ 126.2/6.79) of cinnamyl aldehyde end-groups (J). Prominent signals corresponding to $p$-coumarate (PCA) were observed in the spectra of $\mathrm{MWL}_{\mathrm{u}}$. Cross-signals corresponding to the $\mathrm{C}_{2,6}-\mathrm{H}_{2,6}$ at $\delta_{\mathrm{C}} / \delta_{\mathrm{H}} 130.2 / 7.46$ and $\mathrm{C}_{3,5}-\mathrm{H}_{3,5}$ at $\delta_{\mathrm{C}} / \delta_{\mathrm{H}} 115.4 / 6.76$ correlations of the aromatic ring and signals for the correlations of the unsaturated $\mathrm{C}_{7}-\mathrm{H}_{7}$ at $\delta_{\mathrm{C}} / \delta_{\mathrm{H}} 144.5 / 7.43$ and $\mathrm{C}_{8}-\mathrm{H}_{8}$ at 113.6/6.26 of the $p$-coumarate unit were recognized in the region of the HSQC spectra. Signals corresponding to the $\mathrm{C}_{2}-\mathrm{H}_{2}$ correlations of ferulate moieties (FA) were also observed at $\delta_{\mathrm{C}} / \delta_{\mathrm{H}}$ 111.5/7.49 in the spectra [28]. The correlations corresponding to the unsaturated $\mathrm{C}_{\alpha}-\mathrm{H}_{\alpha}$ overlapped with those of the $p$-coumarate. Tricin $(\mathbf{T})$ is considered a dominant flavones in cereal crop plants, and mainly detected in leaves and stems [29]. It is widely distributed in grasses, including wheat, rice, barley, sorghum, and maize, and can occur in either free or conjugated form. Its signals appeared in the HSQC spectrum at $\delta_{\mathrm{C}} / \delta_{\mathrm{H}} 103.9 / 7.32,106.1 / 7.04$, and 98.8/6.22 corresponded to the $\mathrm{C}_{2,6}^{\prime}-\mathrm{H}_{2,6}^{\prime}, \mathrm{C}_{3}-\mathrm{H}_{3}$, and $\mathrm{C}_{2,6}-\mathrm{H}_{2,6}$ correlations, respectively [30].

Table 4. Assignments of main lignin and polysaccharide ${ }^{13} \mathrm{C}-{ }^{1} \mathrm{H}$ correlation signals in the HSQC spectra of lignin fractions from bamboo D. brandisii shown in Figure 4.

\begin{tabular}{|c|c|c|}
\hline Labels & $\delta_{\mathrm{C}} / \boldsymbol{\delta}_{\mathrm{H}}(\mathbf{p p m})$ & Assignment \\
\hline & & Lignin cross-signals \\
\hline $\mathrm{C}_{\beta}$ & $53.2 / 3.43$ & $\mathrm{C}_{\beta}-\mathrm{H}_{\beta}$ in $\beta-5^{\prime}$ (phenylcoumaran) substructures (C) \\
\hline $\mathrm{B}_{\beta}$ & $53.5 / 3.05$ & $\mathrm{C}_{\beta}-\mathrm{H}_{\beta}$ in $\beta-\beta^{\prime}$ (resinol) substructures (B) \\
\hline$-\mathrm{OMe}$ & $55.9 / 3.72$ & $\mathrm{C}-\mathrm{H}$ in methoxyls $(\mathrm{MeO})$ \\
\hline $\mathrm{A}_{\gamma}$ & $\begin{array}{c}60.1 / 3.22 \text { and } \\
59.67 / 3.59\end{array}$ & $\mathrm{C}_{\gamma}-\mathrm{H}_{\gamma}$ in $\beta-O-4$ ' substructures (A) and others \\
\hline $\mathrm{I}_{\gamma}$ & 61.4/4.09 & $\mathrm{C}_{\gamma}-\mathrm{H}_{\gamma}$ in cinnamyl alcohol end-groups (I) \\
\hline $\mathrm{A}_{\gamma}^{\prime}$ & $62.8 / 4.28$ & $\mathrm{C}_{\gamma}-\mathrm{H}_{\gamma}$ in $\gamma$-acylated $\beta-O-4^{\prime}$ substructures (A') \\
\hline $\mathrm{C}_{\gamma}$ & $62.4 / 3.71$ & $\mathrm{C}_{\gamma}-\mathrm{H}_{\gamma}$ in $\beta-5^{\prime}$ (phenylcoumaran) substructures (C) \\
\hline $\mathrm{I}_{\gamma}^{\prime}$ & $64.1 / 4.77$ & $\mathrm{C}_{\gamma}-\mathrm{H}_{\gamma}$ in $\gamma$-acylated cinnamyl alcohol end-groups (I') \\
\hline $\mathrm{A}_{\alpha}$ & $72.4 / 4.85$ & $\mathrm{C}_{\alpha}-\mathrm{H}_{\alpha}$ in $\beta-O-4^{\prime}$ substructures (A) \\
\hline $\mathbf{B}_{\gamma}$ & $\begin{array}{c}71.0 / 4.17 \text { and } \\
70.9 / 3.80\end{array}$ & $\mathrm{C}_{\gamma}-\mathrm{H}_{\gamma}$ in $\beta-\beta^{\prime}$ (resinol) substructures (B) \\
\hline$A_{\beta}(G)$ & $83.6 / 4.30$ & $\mathrm{C}_{\beta}-\mathrm{H}_{\beta}$ in $\beta-O-4$ ' substructures linked to a guaiacyl unit (A) \\
\hline $\mathrm{C}_{\alpha}$ & $87.1 / 5.45$ & $\mathrm{C}_{\alpha}-\mathrm{H}_{\alpha}$ in $\beta-5^{\prime}$ (phenylcoumaran) substructures (C) \\
\hline $\mathrm{A}_{\beta}(\mathrm{S})$ & $85.8 / 4.10$ & $\mathrm{C}_{\beta}-\mathrm{H}_{\beta}$ in $\beta-O-4^{\prime}$ substructures linked to a syringyl unit (A, erythro) \\
\hline $\mathrm{A}_{\beta}(\mathrm{S})$ & $86.2 / 3.99$ & $\mathrm{C}_{\beta}-\mathrm{H}_{\beta}$ in $\beta-O-4$ ' substructures linked to a syringyl unit (A, threo) \\
\hline $\mathrm{B}_{\alpha}$ & $84.7 / 4.65$ & $\mathrm{C}_{\alpha}-\mathrm{H}_{\alpha}$ in $\beta-\beta^{\prime}$ (resinol) substructures (B) \\
\hline $\mathrm{T}_{2 / 6}^{\prime}$ & $103.9 / 7.32$ & $\mathrm{C}_{2,6}^{\prime}-\mathrm{H}_{2,6}^{\prime}$ in tricin $(\mathrm{T})$ \\
\hline $\mathrm{T}_{3}$ & $106.1 / 7.04$ & $\mathrm{C}_{3}-\mathrm{H}_{3}$ in tricin $(\mathrm{T})$ \\
\hline $\mathrm{T}_{6}$ & $98.8 / 6.22$ & $\mathrm{C}_{2,6}-\mathrm{H}_{2,6}$ in tricin $(\mathrm{T})$ \\
\hline $\mathrm{S}_{2 / 6}$ & $104.3 / 6.70$ & $\mathrm{C}_{2,6}-\mathrm{H}_{2,6}$ in syringyl units $(\mathrm{S})$ \\
\hline $\mathrm{S}_{2 / 6}^{\prime}$ & $106.3 / 7.30$ & $\mathrm{C}_{2,6}-\mathrm{H}_{2,6}$ in oxidized $\left(\mathrm{C}_{\alpha} \mathrm{OOH}\right)$ syringyl units $\left(\mathrm{S}^{\prime}\right)$ \\
\hline
\end{tabular}


Table 4. Cont.

\begin{tabular}{|c|c|c|}
\hline Labels & $\delta_{\mathrm{C}} / \boldsymbol{\delta}_{\mathrm{H}}(\mathbf{p p m})$ & Assignment \\
\hline $\mathrm{G}_{2}$ & $111.1 / 6.97$ & $\mathrm{C}_{2}-\mathrm{H}_{2}$ in guaiacyl units $(\mathrm{G})$ \\
\hline $\mathrm{G}_{5}$ & $115.8 / 6.69$ & $\mathrm{C}_{5}-\mathrm{H}_{5}$ and $\mathrm{C}_{6}-\mathrm{H}_{6}$ in guaiacyl units $(\mathrm{G})$ \\
\hline $\mathbf{G}_{6}$ & $119.1 / 6.79$ & $\mathrm{C}_{6}-\mathrm{H}_{6}$ in guaiacyl units $(\mathbf{G})$ \\
\hline $\mathbf{P C A}_{7}$ & $144.5 / 7.43$ & $\mathrm{C}_{7}-\mathrm{H}_{7}$ in $p$-coumaroylated substructures $(\mathbf{P C A})$ \\
\hline $\mathbf{P C A}_{2 / 6}$ & $130.2 / 7.46$ & $\mathrm{C}_{2.6}-\mathrm{H}_{2.6}$ in $p$-coumaroylated substructures (PCA) \\
\hline $\mathbf{P C A}_{3 / 5}$ & $115.4 / 6.76$ & $\mathrm{C}_{3}-\mathrm{H}_{3}$ and $\mathrm{C}_{5}-\mathrm{H}_{5}$ in $p$-coumaroylated substructures (PCA) \\
\hline $\mathbf{P C A}_{8}$ & $113.6 / 6.26$ & $\mathrm{C}_{8}-\mathrm{H}_{8}$ in $p$-coumaroylated substructures $(\mathbf{P C A})$ \\
\hline $\mathbf{F A}_{2}$ & $111.5 / 7.49$ & $\mathrm{C}_{2}-\mathrm{H}_{2}$ in ferulate $(\mathbf{F A})$ \\
\hline $\mathbf{H}_{2 / 6}$ & $128.0 / 7.17$ & $\mathrm{C}_{2.6}-\mathrm{C}_{2.6}$ in $p$-hydroxyphenyl units $(\mathbf{H})$ \\
\hline $\mathbf{H}_{3 / 5}$ & $115.2 / 6.57$ & $\mathrm{C}_{3.5}-\mathrm{C}_{3.5}$ in $p$-hydroxyphenyl units $(\mathbf{H})$ \\
\hline $\mathbf{J}_{\alpha}$ & $153.5 / 7.61$ & $\mathrm{C}_{\alpha}-\mathrm{H}_{\alpha}$ in cinnamyl aldehyde end-groups $(\mathbf{J})$ \\
\hline $\mathbf{J}_{\beta}$ & $126.2 / 6.79$ & $\mathrm{C}_{\beta}-\mathrm{H}_{\beta}$ in cinnamyl aldehydes end-groups $(\mathbf{J})$ \\
\hline \multirow[t]{2}{*}{$\mathbf{D}_{\beta}^{\prime}$} & $80.3 / 4.54$ & $\mathrm{C}_{\beta}^{\prime}-\mathrm{H}_{\beta}^{\prime}$ in spirodienone substructure $(\mathbf{D})$ \\
\hline & & Polysaccharide cross-signals \\
\hline $\mathbf{X}_{2}$ & $70.1 / 3.33$ & $\mathrm{C}_{2}-\mathrm{H}_{2}$ in $\beta$-D-xylopyranoside \\
\hline $\mathbf{X}_{3}$ & $72.0 / 3.42$ & $\mathrm{C}_{3}-\mathrm{H}_{3}$ in $\beta$-D-xylopyranoside \\
\hline $\mathbf{X}_{4}$ & $75.3 / 3.54$ & $\mathrm{C}_{4}-\mathrm{H}_{4}$ in $\beta$-D-xylopyranoside \\
\hline $\mathbf{X}_{5}$ & $62.8 / 3.40$ & $\mathrm{C}_{5}-\mathrm{H}_{5}$ in $\beta$-D-xylopyranoside \\
\hline
\end{tabular}

Table 5. Structural characteristics (lignin interunit linkages, relative molar composition of the lignin aromatic units, $\mathrm{S} / \mathrm{G}$ ratio and $p$-coumarate/and ferulate content and ratio) from integration of $\mathrm{C}-\mathrm{H}$ correlation signals in the HSQC spectra of the isolated lignin fractions.

\begin{tabular}{ccccc}
\hline & $\mathbf{M W L}_{\mathbf{u}}(\boldsymbol{\%})$ & $\mathbf{M W L}_{\mathbf{p}}(\boldsymbol{\%})$ & $\mathbf{E O L}(\boldsymbol{\%})$ & $\mathbf{C E L}(\boldsymbol{\%})$ \\
\hline Lignin interunit linkages & & & & \\
$\beta-O-4$ ' substructure (A) & 89.4 & 82.1 & 72.3 & 94.5 \\
$\beta-\beta$ ' resinol substructures (B) & 5.5 & 2.6 & 20.0 & 0 \\
$\beta-5$ ' phenylcoumaran substructures (C) & 5.1 & 15.3 & 7.7 & 5.5 \\
Lignin aromatic units & & & & \\
H & 3.5 & - & 19.6 & 8.0 \\
G & 49.5 & 48.5 & 42.4 & 47.5 \\
S & 47.0 & 51.5 & 38.0 & 44.5 \\
S/G ratio & 0.95 & 1.06 & 0.90 & 0.94 \\
$p$-Hydroxycinnamates & & & & \\
$p$-Coumarates & 97.5 & 84.9 & 82.1 & 76.6 \\
Ferulates & 9.3 & 15.1 & 17.9 & 23.4 \\
$p$-Coumarates/ferulates ratio & 9.75 & 5.62 & 4.59 & 3.27 \\
\hline
\end{tabular}

Substantial structural changes were observed when comparing the HSQC spectrum of $\mathrm{MWL}_{\mathrm{p}} \mathrm{EOL}$ and CEL with the $\mathrm{MWL}_{\mathrm{u}}$, where the presence of a greater number of signals and broader signals implied more complicated lignin structures after the fractionation processes. For $\mathrm{MWL}_{\mathrm{p}}$, a characteristic is the absence of signals corresponding to the $\mathbf{C}_{\boldsymbol{\beta}}$ and $\mathbf{B}_{\boldsymbol{\beta}}$, suggesting the degradation of $\beta$-aryl ether and resinol. Lignin degradation was also apparent as a result of the disappearance of $\mathbf{D}_{\boldsymbol{\beta}^{\prime}}$, $\mathbf{B}_{\boldsymbol{\alpha}}, \mathbf{F} \mathbf{A}_{\mathbf{2}}, \mathbf{H}_{\mathbf{2} / \mathbf{6}}, \mathbf{J}_{\boldsymbol{\alpha}}$, and $\mathbf{J}_{\boldsymbol{\beta}}$ cross-peaks, and the decreased intensities of $\mathbf{S}$ and $\mathbf{G}$ correlations. The 
aromatic area was almost identical for both MWLs from the original and treated bamboo. Interestingly, the spectrum of $\mathrm{MWL}_{\mathrm{p}}$ showed predominant carbohydrate cross-signals $\left(\mathbf{X}_{\mathbf{2}}, \mathbf{X}_{\mathbf{3}}\right.$, and $\left.\mathbf{X}_{\mathbf{4}}\right)$, which partially overlapped with some lignin moieties. The EOL and CEL displayed the same features which may account for the signal expression of some degraded monosaccharide. As shown in the spectra in Figure 4, it was obvious that the isolated CEL contained significant amounts of carbohydrates as colored in grey in the spectrum. The EOL spectra in the side chain region showed the disappearance of the intensity of the peaks corresponding to $\mathbf{C}_{\boldsymbol{\beta}}, \mathbf{I}_{\gamma}$, and $\mathbf{D}_{\boldsymbol{\beta}^{\prime}}$, validating the degradation of $\beta$-aryl ether, cinnamyl alcohol, and spirodienone units.

The relative abundances of the main lignin interunit linkages and end-groups, as the molar percentage of the different lignin units $(\mathbf{H}, \mathbf{G}$, and $\mathbf{S}), p$-coumarates, and ferulates, as well as the molar $\mathrm{S} / \mathrm{G}$ ratios of the lignin in bamboo, estimated from volume integration of contours in the HSQC spectra, are shown in Table 5. With respect to the different linkage types, $\mathrm{MWL}_{\mathrm{u}}$ showed a predominance

$\beta-O-4$ ' aryl ether linkages (A, $89.4 \%$ of the total side chains) followed by $\beta$ - $\beta$ ' resinol-type units (B, $5.5 \%)$ and a lower amount of $\beta-5$ ' phenylcoumaran substructures $(\mathbf{C}, 5.1 \%)$. As compared with $\mathrm{MWL}_{\mathrm{u}}$, $\mathrm{MWL}_{\mathrm{p}}$ demonstrated a lower relative proportion of $\beta-O-4^{\prime}$ and $\beta-\beta^{\prime}$, which resulted in a higher relative proportion of $\beta-5$ ' phenylcoumaran substructure. The data in Table 5 clearly showed that the amount of $\beta-O-4$ ' in the recovered EOL samples decreased. Moreover, the $\mathrm{S} / \mathrm{G}$ ratios were estimated to be 0.95 , 1.06, 0.90, and 0.94 for $\mathrm{MWL}_{\mathrm{u}}, \mathrm{MWL}_{\mathrm{p}}, \mathrm{EOL}$, and CEL, respectively. Similarly as observed by Py-GC/MS of the raw bamboo material and pretreated bamboo, the $S / G$ ratio of $M_{\mathrm{u}}$ was lower than that of $\mathrm{MWL}_{\mathrm{p}}$, indicating a decrease of $\mathrm{H}$ and $\mathrm{G}$ units and an increase of S lignin units during ethanol organosolv treatment [31]. Moreover, the S/G ratio from HSQC NMR spectra was higher than that estimated from Py-GC/MS, corroborating the same observation recently reported by Li et al. [32]. However, the results demonstrate that those methods yield relatively similar trends of S/G ratio.

\section{Experimental Section}

\subsection{Materials}

Three year old bamboo (Dendrocalamus brandisii) was harvested from Yunnan Province, in the southeast of China. The bamboo was manually chipped and smashed before use. The powder obtained was screened to get particles sized in 40-60 mesh. Subsequently, they were extracted with toluene/ethanol $(2: 1, v / v)$ in a Soxhlet apparatus for $8 \mathrm{~h}$. The cellulolytic enzymes used in this study were Celluclase $1.5 \mathrm{~L}$ and Ultraflo L (Novozymes, Tianjin, China) with activities of $700 \mathrm{EGU} / \mathrm{g}$ and $45 \mathrm{FBG} / \mathrm{g}$, respectively. Dimethyl sulfoxide- $d_{6}$ (DMSO- $d_{6}$ ) was obtained from Aldrich (St. Louis, MO, USA). For analysis, deionized (DI) water was obtained by passing distilled water through a filter apparatus (Pall Corporation, Port Washington, NY, USA). Unless otherwise stated, reagents were purchased from Beijing Chemicals (Beijing, China), and were analytical grade and used as received.

\subsection{Isolation of Lignins}

The fractionation sequence of the lignin fractions is schematically illustrated in Figure 6. Bamboo sample was pretreated by ethanol organosolv using $70 \%(v / v)$ aqueous ethanol solution at $180{ }^{\circ} \mathrm{C}$ for 2 
$\mathrm{h}$ with a solid to liquid ratio of 1:10 ( $1 \mathrm{~g}$ solid and $10 \mathrm{~g}$ liquid) in a $1.0 \mathrm{~L}$ pressure reactor with a temperature controller (Parr Instrument Company, Moline, IL, USA). The pretreated bamboo was filtered and dried. After filtration, the filtrate was concentrated to $40 \mathrm{~mL}$ under reduced pressure at $50{ }^{\circ} \mathrm{C}$. EOL was obtained by precipitation at $\mathrm{pH} 2.0$ with $6 \mathrm{M} \mathrm{HCl}$ and collected by centrifugation as well as freeze-drying.

Figure 6. Scheme for the extraction of EOL, MWL, CEL, and REL from bamboo.

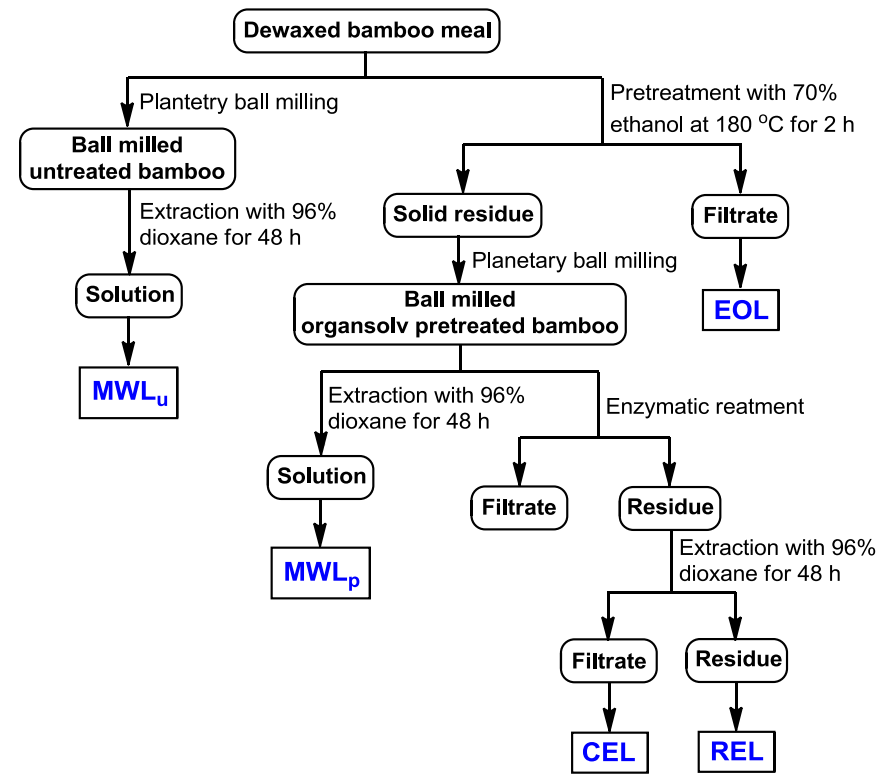

MWL was isolated from the raw and pretreated bamboo sample according to the method described by Björkman [33]. The samples were firstly milled using a planetary ball milling (Fritsch, Idar-Oberstein, Germany) in a $500 \mathrm{~mL} \mathrm{ZrO}$ bowl with mixed balls, 10 balls of $2 \mathrm{~cm}$ diameter and 25 balls of $1 \mathrm{~cm}$ diameter. The milling was run under a nitrogen atmosphere at $500 \mathrm{rpm}$ with $10 \mathrm{~min}$ of rest after every $10 \mathrm{~min}$ of milling. Five hours of milling was performed to minimize the structural changes of lignin caused by ball milling. The milled materials were extracted twice with $p$-dioxane-water solution $(96 \% \mathrm{v} / \mathrm{v})$ in a shaker for $48 \mathrm{~h}$ in the dark, respectively. The $p$-dioxane-water extracts were combined and the solvent volume was reduced to about $40 \mathrm{~mL}$ using a rotary evaporator (Shanghai Ya Rong Biochemical Instrument Factory, Shanghai, China). Then this solution was added dropwise to deionized (DI) water $(200 \mathrm{~mL})$ while stirring and then freeze-dried. The crude MWL was dissolved in $90 \%$ acetic acid $(20 \mathrm{~mL})$ and precipitated in DI water $(400 \mathrm{~mL})$. The solution was centrifuged and the solid part was dissolved in 1,2-dichloroethane/ethanol $(10 \mathrm{~mL}, 2: 1 \mathrm{v} / \mathrm{v})$ and precipitated in diethyl ether $(200 \mathrm{~mL})$. Subsequently, the solution was centrifuged and the solid material was washed with petroleum ether $(2 \times 100 \mathrm{~mL})$. The lignin sample obtained was freeze-dried, referred as $\mathrm{MWL}_{\mathrm{u}}$ and $\mathrm{MWL}_{\mathrm{p}}$ respectively. The final yield was around $3 \%-5 \%$ of the original lignin content.

CEL was isolated according to the method described as Chang et al. [13] with minor modification. Briefly, $10 \mathrm{~g}$ of pretreated sample was incubated twice in acetate buffer (100 mL, pH 4.8) with $20 \mathrm{~mL}$ Ultraflo L enzyme and $10 \mathrm{~mL}$ of cellulase at $50{ }^{\circ} \mathrm{C}$ for $24 \mathrm{~h}$. The reaction system was centrifuged, the supernatant was removed, and the residue was again suspended in acetate buffer $(50 \mathrm{~mL}, \mathrm{pH} 4.8)$ and 
treated with Ultraflo $(10 \mathrm{~mL})$ and cellulase $(5 \mathrm{~mL})$ for additional $24 \mathrm{~h}$ at $50{ }^{\circ} \mathrm{C}$. After filtration, the enzyme-treated residue was treated by extractions $(2 \times 24 \mathrm{~h})$ with dioxane/water $(100 \mathrm{~mL}, 96: 4, v / v)$. The solution was collected by centrifugation and concentration. The crude CEL was freeze-dried and purified as MWL. The residue after CEL isolation was freeze-dried and named as residual enzyme lignin (REL).

\subsection{Chemical Composition Analysis}

The chemical composition of the untreated and pretreated bamboo samples and the lignin samples were determined according to National Renewable Energy Laboratory (NREL) standard analytical laboratory procedure [34]. Briefly, samples ( $300 \mathrm{mg})$ were hydrolyzed with $72 \% \mathrm{H}_{2} \mathrm{SO}_{4}$ for $1 \mathrm{~h}$ at 30 ${ }^{\circ} \mathrm{C}$ followed by high temperature hydrolysis at $121{ }^{\circ} \mathrm{C}$ for $1 \mathrm{~h}$ after dilution to $4 \% \mathrm{H}_{2} \mathrm{SO}_{4}$. After hydrolysis, the samples were diluted and quantified with High Performance Anion Exchange Chromatography with Pulsed-Amperometric Detection (HPAEC-PAD) on a Dionex ICS3000. Separation was achieved with a CarboPac ${ }^{\mathrm{TM}}$ PA-20 analytical column $(3 \times 150 \mathrm{~mm}$, Dionex, Sunnyvale, CA, USA) and a CarboPac ${ }^{\mathrm{TM}}$ PA-20 guard column $(3 \times 30 \mathrm{~mm}$, Dionex, Sunnyvale, CA, USA). Neutral sugars and uronic acids were separated in isocratic $5 \mathrm{mM} \mathrm{NaOH}$ (carbonate-free and purged with nitrogen) for $20 \mathrm{~min}$, followed by a $0.75 \mathrm{mM} \mathrm{NaAc}$ gradient in $5 \mathrm{mM} \mathrm{NaOH}$ for $15 \mathrm{~min}$ with a flow rate of $0.4 \mathrm{~mL} / \mathrm{min}$. Calibration was performed with standard solutions of sugars, and the relative standard deviation of the results was below $6 \%$. Ash content was determined by burning the material in an oven at $600{ }^{\circ} \mathrm{C}$ according to the method of NREL/TP-510-42622 [35].

\subsection{Analytical Pyrolysis}

Analytical Py-GC/MS of the raw and the pretreated bamboo (about $100 \mu \mathrm{g}$ ) were performed with a CDS Pyroprobe 5200HP pyrolyser autosampler (Chemical Data Systems, Oxford, PA, USA) attached to a PerkinElmer GC/MS apparatus (Clarus 560, PerkinElmer, Waltham, MA, USA) using a $30 \times 0.25$ mm column (film thickness $0.25 \mu \mathrm{m}$ ). The pyrolysis was carried out into a glass liner at $500{ }^{\circ} \mathrm{C}$ for $4 \mathrm{~s}$ with the heating rate of $20{ }^{\circ} \mathrm{C} / \mathrm{ms}$. The chromatograph was programmed from $40{ }^{\circ} \mathrm{C}(3 \mathrm{~min})$ to $300{ }^{\circ} \mathrm{C}$ at a rate of $6^{\circ} \mathrm{C} / \mathrm{min}$. Helium was used as the carrier gas with a constant flow rate of $1 \mathrm{~mL} / \mathrm{min}$ and a 1:80 split ratio. The mass spectrometer was operated in EI mode $(70 \mathrm{eV})$ and the mass spectra were obtained from $\mathrm{m} / \mathrm{z}, 20$ to 400 . The injector temperature was kept at $300{ }^{\circ} \mathrm{C}$, while the GC/MS interface was kept at $280{ }^{\circ} \mathrm{C}$ [36]. The compounds were identified by comparison with those reported in the literature and in the Wiley and NIST computer libraries [37-39]. Relative peak molar areas (obtained by dividing the peak area by the molecular weight) were calculated for each lignin pyrolysis products. The syringyl/guaiacyl (S/G) ratio was calculated by dividing the sum of peak areas from the sum of the peak areas of syringyl units and by the sum of guaiacyl derivatives of the selected markers, obtained by integration of the peak areas and considering the total peak area as $100 \%$. 


\subsection{FT-IR Analysis}

FT-IR spectra were obtained on a spectrophotometer (Nicolet iN10 FT-IR Microscope, Thermo Fisher Scientific, Waltham, MA, USA)) equipped with a liquid nitrogen cooled mercury cadmium telluride (MCT) detector in the range $4000-650 \mathrm{~cm}^{-1}$ at $4 \mathrm{~cm}^{-1}$ resolution and 128 scans per sample.

\subsection{Molecular Weight Analysis}

Molecular weights of the lignin fractions were measured by GPC with an ultraviolet detector (UV) (Agilent Technologies, Santa Clara, CA, USA) at $240 \mathrm{~nm}$ on a PL-gel $10 \mathrm{~mm}$ Mixed-B $7.5 \mathrm{~mm}$ i.d. calibrated with PL polystyrene. The calibration curve was created by fitting a polynomial equation to the retention volumes obtained from a series of narrow molecular weight distribution polystyrene standards. The samples were acetylated with acetic anhydride before determination according to the literature $[27,40]$ with mild modification. Namely, about $20 \mathrm{mg}$ of dry lignin sample was dissolved in a 1:1 mixture of acetic anhydride/pyridine $(1 \mathrm{~mL})$ and stirred at room temperature in darkness for $24 \mathrm{~h}$. Ethanol $(25 \mathrm{~mL})$ was added to the reaction mixture, left for $30 \mathrm{~min}$, and then removed with a rotary evaporator. The addition and removal of ethanol was repeated several times until all traces of acetic acid were removed from the lignin sample. The residue was dissolved in chloroform $(2 \mathrm{~mL})$ and added to diethyl ether $(100 \mathrm{~mL})$. Then the obtained solution was centrifuged. Subsequently, the precipitate was washed three times with diethyl ether and dried in a vacuum over as the acetylated lignin. The derivatized lignin was dissolved in tetrahydrofuran (THF) $(1 \mathrm{mg} / \mathrm{mL})$, and the solution was filtered through a $0.45 \mu \mathrm{m}$ filter. The filtered solution $(20 \mu \mathrm{L})$ was injected into the HPLC system and the eluted compounds were detected using an UV detector set at $280 \mathrm{~nm}$ [41].

\subsection{NMR Spectra}

All NMR spectra were recorded on a Bruker AVIII spectrometer (400M Hz) (Bruker, Zurich, Switzerland) equipped with a $z$-gradient triple resonance probe at $100 \mathrm{MHz}$ in DMSO- $d_{6} .20 \mathrm{mg}$ of the sample was dissolved in $1 \mathrm{~mL}$ DMSO- $d_{6}$. The spectral widths were 5000 and $25625 \mathrm{HZ}$ for the ${ }^{1} \mathrm{H}-{ }^{13} \mathrm{C}$ dimensions, respectively, and the numbers of collected complex points were 2048 for the ${ }^{1} \mathrm{H}$ dimensions with a recycle delay of $5 \mathrm{~s}$. The number of transients was 64, and 256 time increments were always recorded in the ${ }^{13} \mathrm{C}$-dimensions. The ${ }^{1} \mathrm{~J}_{\mathrm{CH}}$ was set to $146 \mathrm{~Hz}$. Prior to Fourier transform the data matrices were zero filled up to 1024 points in the ${ }^{13} \mathrm{C}$-dimensions. Signals were assigned by comparison to literature spectra. The $\mathrm{C}-\mathrm{H}$ correlations from $\mathrm{S}$ and $\mathrm{G}$ type units in the aromatic region were used to estimate the $\mathrm{S} / \mathrm{G}$ ratio of lignin and the percentage of oxidized units.

\section{Conclusions}

During ethanol organosolv pretreatment, the main degraded compounds are lignin, hemicelluloses, and less ordered cellulose, while leaving most of the ordered cellulose undigested. Furthermore, in this process, the G lignin moiety was preferably degraded as indicated by solid-state NMR and Py-GC/MS. It was found that the milled wood lignin extracted from the original bamboo was HGS lignin with $\mathrm{G}>\mathrm{S}>\mathrm{H}$. The spectroscopic results suggested that the ethanol organosolv treatment of the bamboo material predominantly involved the cleavage of $\beta$-aryl ether bonds. The lower molecular weight of 
EOL demonstrated that this process degraded the lignin to a noticeable extent while HSQC NMR and FT-IR spectra showed that the process did not strongly affect lignin primary structures.

\section{Acknowledgments}

The authors are grateful for the financial support from the Major State Basic Research Projects of China (973-2010CB732203/4) and National Natural Science Foundation of China (31110103902), and the Specific Programs in Graduate Science and Technology Innovation of Beijing Forestry University (NO. BLYJ201314).

\section{Conflicts and Interest}

The authors declare no conflict of interest.

\section{References}

1. Samuel, R.; Pu, Y.; Raman, B.; Ragauskas, A.J. Structural characterization and comparison of switchgrass ball-milled lignin before and after dilute acid pretreatment. Appl. Biochem. Biotechnol. 2010, 162, 62-74.

2. del Río, J.C.; Prinsen, P.; Rencoret, J.; Nieto, L.; Jiménez-Barbero, J.; Ralph, J.; Martínez, Á.T.; Gutiérrez, A. Structural characterization of the lignin in the cortex and pith of elephant grass (Pennisetum purpureum) stems. J. Agric. Food. Chem. 2012, 60, 3619-3634.

3. Xu, F.; Yu, J.M.; Tesso, T.; Dowell, F.; Wang, D.H. Qualitative and quantitative analysis of lignocellulosic biomass using infrared techniques: A mini-review. Appl. Energy 2013, 104, 801-809.

4. Gao, A.H.; Bule, M.V.; Laskar, D.D.; Chen, S. Structural and thermal characterization of wheat straw pretreated with aqueous ammonia soaking. J. Agric. Food. Chem. 2012, 60, 8632-8639.

5. Guerra, A.; Filpponen, I.; Lucia, L.A.; Argyropoulos, D.S. Comparative evaluation of three lignin isolation protocols for various wood species. J. Agric. Food Chem. 2006, 54, 9696-9705.

6. Sasaki, C.; Wanaka, M.; Takagi, H.; Tamura, S.; Asada, C.; Nakamura, Y. Evaluation of epoxy resins synthesized from steam-exploded bamboo lignin. Ind. Crop. Prod. 2013, 43, 757-761.

7. Shi, Z.J.; Xiao, L.P.; Xu, F.; Sun, R.C. Physicochemical characterization of lignin fractions sequentially isolated from bamboo (Dendrocalamus brandisii) with hot water and alkaline ethanol solution. J. Appl. Polym. Sci. 2012, 125, 3290-3301.

8. Obama, P.; Ricochon, G.; Muniglia, L.; Brosse, N. Combination of enzymatic hydrolysis and ethanol organosolv pretreatments: Effect on lignin structures, delignification yields and cellulose-to-glucose conversion. Bioresour. Technol. 2012, 112, 156-163.

9. Romaní, A.; Garrote, G.; López, F.; Parajó, J.C. Eucalyptus globulus wood fractionation by autohydrolysis and organosolv delignification. Bioresour. Technol. 2011, 102, 5896-5904.

10. El Hage, R.; Perrin, D.; Brosse, N. Effect of the pre-treatment severity on the antioxidant properties of ethanol organosolv Miscanthus x giganteus lignin. Nature Resour. 2012, 3, 29-34.

11. Hu, G.; Cateto, C.; Pu, Y.; Samuel, R.; Ragauskas, A.J. Structural characterization of switchgrass lignin after ethanol organosolv pretreatment. Energy Fuels 2011, 26, 740-745. 
12. Bauer, S.; Sorek, H.; Mitchell, V.D.; Ibáñez, A.B.; Wemmer, D.E. Characterization of Miscanthus giganteus lignin isolated by ethanol organosolv process under reflux condition. J. Agric. Food Chem. 2012, 60, 8203-8212.

13. Chang, H.; Cowling, E.B.; Brown, W. Comparative studies on cellulolytic enzyme lignin and milled wood lignin of sweetgum and spruce. Holzforschung 1975, 29, 153-159.

14. Shi, Z.J.; Xiao, L.P.; Deng, J.; Xu, F.; Sun, R.C. Isolation and characterization of soluble polysaccharides of Dendrocalamus brandisii. BioResources 2011, 6, 5151-5166.

15. Zhang, A.; Lu, F.; Sun, R.C.; Ralph, J. Isolation of cellulolytic enzyme lignin from wood preswollen/dissolved in dimethyl sulfoxide/N-methylimidazole. J. Agric. Food Chem. 2010, 58, 3446-3450.

16. Yuan, T.Q.; Sun, S.N.; Xu, F.; Sun, R.C. Structural characterization of lignin from triploid of Populus tomentosa Carr. J. Agric. Food Chem. 2011, 59, 6605-6615.

17. Mihalcik, D.J.; Mullen, C.A.; Boateng, A.A. Screening acidic zeolites for catalytic fast pyrolysis of biomass and its components. J. Anal. Appl. Pyrolysis 2011, 92, 224-232.

18. Del Río, J.C.; Gutiérrez, A.; Rodríguez, I.M.; Ibarra, D.; Martinez, A.T. Composition of non-woody plant lignins and cinnamic acids by Py-GC/MS, Py/TMAH and FT-IR. J. Anal. Appl. Pyrolysis 2007, 79, 39-46.

19. Lima, M.A.; Lavorente G.B.; da Silva, H.KP.; Bragatto, J.; Rezende, C.A.; Bernardinelli, O.D.; de Azevedo, E.R.; Gomez, L.D.; McQueen-Mason, S.J.; Labate, C.A.; et al. Effects of pretreatment on morphology, chemical composition and enzymatic digestibility of eucalyptus bark: A potentially valuable source of fermentable sugars for biofuel production-Part 1. Biotechnol. Biofuels 2013, 6, 1-17.

20. Peng, P.; Peng, F.; Bian, J.; Xu, F.; Sun, R.C. A comparative study of bamboo (Phyllostachys incarnata Wen) milled wood lignin and the successively alkali-fractionated lignins. Wood Sci. Technol. 2012, 46, 871-885.

21. Faix, O. Classification of lignins from different botanical origins by FT-IR spectroscopy. Holzforschung 2009, 45, 21-22.

22. Xiao, L.P.; Shi, Z.J.; Xu, F.; Sun, R.C. Characterization of MWLs from Tamarix ramosissima isolated before and after hydrothermal treatment by spectroscopical and wet chemical methods. Holzforschung 2012, 66, 295-302.

23. Kim, H.; Ralph, J. Solution-state 2D NMR of ball-milled plant cell wall gels in DMSO- $d_{6} /$ pyridine- $d_{5}$. Org. Biomol. Chem. 2010, 8, 576-591.

24. Samuel, R.; Foston, M.; Jiang, N.; Allison, L.; Ragauskas, A.J. Structural changes in switchgrass lignin and hemicelluloses during pretreatments by NMR analysis. Polym. Degrad. Stab. 2011, 96, 2002-2009.

25. Vanderghem, C.; Richel, A.; Jacquet, N.; Blecker, C.; Paquot, M. Impact of formic/acetic acid and ammonia pre-treatments on chemical structure and physico-chemical properties of Miscanthus $x$ giganteus lignins. Polym. Degrad. Stab.2011, 96, 1761-1770.

26. Rencoret, J.; Marques, G.; Gutiérrez, A.; Nieto, L.; Jiménez-Barbero, J.; Martínez, Á.T.; del Río, J.C. Isolation and structural characterization of the milled-wood lignin from Paulownia fortunei wood. Ind. Crop. Prod. 2009, 30, 137-143. 
27. El Hage, R.; Brosse, N.; Chrusciel, L.; Sanchez, C.; Sannigrahi, P.; Ragauskas, A. Characterization of milled wood lignin and ethanol organosolv lignin from miscanthus. Polym. Degrad. Stab. 2009, 94, 1632-1638.

28. Yelle, D.J.; Kaparaju, P.; Hunt, C.G.; Hirth, K.; Kim, H.; Ralph, J.; Felby, C. Two-imensional NMR evidence for cleavage of lignin and xylan substituents in wheat straw through hydrothermal pretreatment and enzymatic hydrolysis. Bioenerg. Res. 2013, 6, 211-221.

29. Zhou, J.M.; Ibrahim, R.K. Tricin-A potential multifunctional nutraceutical. Phytochem. Rev. 2010, 9, 413-424.

30. Del Río, J.C.; Rencoret Pazo, J.; Prinsen, P.; Martínez Ferrer, Á.T.; Ralph, J.; Gutiérrez Suárez, A. Structural characterization of wheat straw lignin as revealed by analytical pyrolysis, 2D-NMR, and reductive cleavage methods. J. Agric. Food Chem. 2012, 60, 5922-5953.

31. Gutiérrez, A.; del Río, J.C.; Ibarra, D.; Rencoret, J.; Romero, J.; Speranza, M.; Camarero, S.; Martínez, M.J.; Martínez, Á.T. Enzymatic removal of free and conjugated sterols forming pitch deposits in environmentally sound bleaching of eucalypt paper pulp. Environ. Sci. Technol. 2006, 40, 3416-3422.

32. Li, M.; Foster, C.; Kelkar, S.; Pu, Y.; Holmes, D.; Ragauskas, A.; Saffron, C.M.; Hodge, D.B. Structural characterization of alkaline hydrogen peroxide pretreated grasses exhibiting diverse lignin phenotypes. Biotechnol. Biofuels 2012, 5, 1-15.

33. Björkman, A. Studies on finely divided wood. Part 1. Extraction of lignin with neutral solvents. Svensk. Papperst. 1956, 59, 477-485.

34. Sluiter, A.; Hames, B.; Ruiz, R.; Scarlata, C.; Sluiter, J.; Templeton, D.; Crocker, D. Determination of Structural Carbohydrates and Lignin in Biomass; Technical Report for Laboratory Analytical Procedure (LAP), NREL: Golden, CO, USA, April 2008.

35. Sluiter, A.; Hames, B.; Ruiz, R.; Scarlata, C.; Sluiter, J.; Templeton, D. Determination of Ash in Biomass; Technical Report for Laboratory Analytical Procedure (LAP), NREL: Golden, CO, USA, January 2008.

36. Xiao, L.P.; Shi, Z.J.; Xu, F.; Sun, R.C. Characterization of lignins isolated with alkaline ethanol from the hydrothermal pretreated Tamarix ramosissima. Bioenerg. Res. 2013, 6, 519-532.

37. Ralph, J.; Hatfield, R.D. Pyrolysis-GC-MS characterization of forage materials. J. Agric. Food Chem. 1991, 39, 1426-1437.

38. Del Río, J.C.; Rencoret, J.; Gutiérrez, A.; Nieto, L.; Jiménez-Barbero, J.; Martínez, Á.T. Structural characterization of guaiacyl-rich lignins in flax (Linum usitatissimum) fibers and shives. J. Agric. Food Chem. 2011, 59, 11088-11099.

39. Nunes, C.A.; Lima, C.F.; Barbosa, L.C.; Colodette, J.L.; Gouveia, A.; Silvério, F.O. Determination of Eucalyptus spp lignin $S / G$ ratio: A comparison between methods. Bioresour. Technol. 2010, 101, 4056-4061.

40. Gellerstedt, G. Gel Permeation Chromatography. In Methods in Lignin Chemistry, Stephen, Y.L., Carlton W.D., Eds.; Springer-Verlag: Heidelberg, Gernmany, 1992; pp. 487-497. 
41. Kang, S.M.; Xiao, L.P.; Meng, L.Y.; Zhang, X.M.; Sun, R.C. Isolation and structural characterization of ligin from cotton stalk treated in an ammonia hydrothermal system. Int. J. Mol. Sci. 2012, 13, 15209-15226.

(C) 2013 by the authors; licensee MDPI, Basel, Switzerland. This article is an open access article distributed under the terms and conditions of the Creative Commons Attribution license (http://creativecommons.org/licenses/by/3.0/). 